\title{
OPTIMALISASI PEMAHAMAN HUKUM MASYARAKAT MELALUI MEDIA SOSIAL SEBAGAI SARANA EDUKASI DALAM UPAYA MEMINIMALISIR DAMPAK COVID-19 DI SULAWESI TENGGARA
}

${ }^{1}$ Guasman Tatawu, ${ }^{2}$ Nur Intan, ${ }^{3}$ Lade Sirjon, ${ }^{4}$ Rahman Hasima, ${ }^{5}$ La Ode Muhamad Sulihin ${ }^{12345}$ Program Studi Ilmu Hukum Fakultas Hukum Universitas Halu Oleo

Email: rahmanhasima@uho.ac.id,

\section{RINGKASAN}

Tujuan kegiatan pengabdian ini adalah untuk mengoptimalkan pemahaman masyarakat melalui media sosial sebagai sarana edukasi dalam upaya meminimalisir dampak covid-19 di Provinsi Sulawesi Tenggara. Program kerja yang dilaksanakan oleh peserta KKN Tematik adalah sebagai berikut: 1) sosialisasi atau penyuluhan kepada masyarakat mengenai pencegahan Covid-19 seperti penerapan social distancing atau physical distancing dan penerapan new normal serta cara menggunakan masker dalam bentuk poster dan 2) membagikan masker, hand sanitizer serta sterilisasi fasilitas umum dan fasilitas sosial kepada masyarakat bekerjasama dengan Palang Merah Indonesia di Kota Kendari. Semua program tersebut disampaikan dengan cara memanfaatkan media sosial instagram sebagai sarana edukasi dalam upaya meminimalisir dampak covid-19. Hasil kegiatan menunjukan bahwa tingkat pemahaman dan pengetahuan masyarakat dalam upaya mencegah dan meminimalisir dampak covid-19 di Sulawesi Tenggara baik dan kegiatan pengabdian penanggulangan covid-19 ini sangat membantu dan memberikan kemudahan bagi masyarakat Sulawesi Tenggara dalam mencegah penyebaran covid-19.

\section{Kata kunci: Pemahaman Hukum; Covid-19; Media Sosial; Edukasi}

\section{A. Analisis Situasi}

Sejak pemerintah mengumumkan keberadaan kasus Covid-19 pertama di Indonesia pada tanggal 2 Maret 2020 lalu, media sosial menjadi salah satu hal penting dalam penyampaian informasi dari pemerintah kepada masyarakat mengenai penyakit pandemik yang mengancam masyarakat tersebut. Segala bentuk informasi baik melalui jejaring sosial (whatsapp, facebook, instagram, twitter, dll), maupun website resmi yang dibuat oleh pemerintah sangat berguna bagi masyarakat dalam menghadapi dan menanggulangi wabah ini.

Wabah ini pertama kali muncul di wilayah Wuhan, China dan terus menyebar hingga ke negara lain termasuk Indonesia. Informasi tersebut tidak mungkin kita dapatkan dengan segera jika tidak terdapat saluran informasi yang memungkinkan hal tersebut terjadi, yakni media sosial. Serta informasi dasar mengenai hal-hal yang 
berkaitan dengan penyakit ini dapat dengan mudah kita temukan di platform media sosial saat ini. Maka dari itu tidak dapat dipungkiri bahwa media sosial memiliki peran besar dalam menyebarkan informasi, dan hal ini tentunya dapat dimanfaatkan baik oleh pemerintah maupun masyarakat guna menanggulangi masalah ini.

Pemerintah Indonesia telah meluncukan situs resmi penanganan Covid-19 untuk masyarakat yakni www.covid19.go.id guna memberikan edukasi kepada masyarakat terkait Covid-19. Ketua Gugus Tugas Percepatan Penanganan Covid-19 Doni Monardo mengatakan, portal ini diharapkan menjadi sumber informasi resmi penanggulangan virus corona sebagai penyebab Covid-19, yang kini menjadi pandemi global.

Namun beberapa media khususnya media sosial meletakan kalimat-kalimat yang memancing rasa ingin tahu pembaca pada judul berita (clickbait). Tidak jarang, judul yang diberikan justru memuat substansi yang sedikit berbeda dengan isinya. Sayangnya, dalam situasi serangan virus yang telah ditetapkan World Health Organization (WHO) sebagai pandemi ini. Dalam pemberitaan korban COVID-19 misalnya, media sosial cenderung menjual embel-embel gelar dan instansi korban dalam judulnya. Contohnya pada judul berita "Pegawai Bank BNI Terindikasi Corona". Alih-alih memperingati masyarakat yang mungkin pernah berinteraksi dengan korban, ketakutan dan spekulasi negatif masyarakat akan instansi tersebut justru yang terjadi.

Selain itu, sarana bertukar informasi yang semakin berkembang juga mendorong individu-individu untuk ambil bagian dari penyebaran informasi. Meski memiliki dampak positif, fenomena ini justru mempercepat munculnya informasi-informasi yang tidak bertanggung jawab. Berbagai hoaks yang terlalu sering beredar seringkali meningkatkan ketakutan atau bahkan menimbulkan rasa acuh tak acuh masyarakat akan bahayanya virus ini.

Salah satu cara mencegah penyebaran covid-19 adalah melalui peran dari perguruan tinggi. perguruan tinggi merupakan tempat pembinaan mental, moral dan spiritual. pendidikan di perguruan tinggi dilaksanakan dengan cara membekali dan mengembangkan religiusitas, kecakapan, keterampilan, kepekaan dan kecintaan 
mahasiswa terhadap pemuliaan kehidupan umat manusia pada umumnya dan masyarakat Indonesia pada khususnya.

Beberapa permasalahan yang dihadapi oleh pemerintah Provinsi Sulawesi Tenggara dalam pemyebarluaskan informasi tentang covid-19 antara lain masih banyak beredar berita bohong ( hoax) melalui media sosial seperti instagram, whatsapp dan lainlain. Secara spesifik dapat dijabarkan masalah yang dialami oleh mitra yaitu sebagai berikut: (a) pemahaman dan pengetahuan masyarakat tentang covid-19 masih kurang, dan (b) kurangnya kesadaran masyarakat akan bahaya dan dampak covid-19 hal ini dapat dilihat dari budaya masyarakat yang tidak menerapkan social distancing dan physical distancing serta kurang penerapan perilaku hidup bersih dan sehat dalam lingkungan masyarakat yang dilaksanakan oleh Mahasiswa Peserta KKN Tematik Universitas Halu Oleo di lokasi masing-masing peserta dengan tetap menerapkan protokol kesehatan.

\section{A. METOde PELAKSANAAN}

Penyampaian pemahaman hukum kepada masyarakat harus diberikan dengan metode yang tepat dengan memperhatikan kondisi sosial dan budaya masyarakat, berikut metode yang akan diterapkan, Pertama; metode pendekatan secara tidak langsung dalam bentuk poster dengan cara memanfaatkan media sosial, Kedua; metode pendekatan secara langsung kepada masyarakat melalui sosialisasi atau mendatangi langsung rumah warga (door to door) dengan tetap menerapkan protokol kesehatan. Adapun bentuk kegiatan yang akan dilakukan adalah sosialisasi atau penyuluhan kepada masyarakat mengenai pencegahan Covid-19 seperti penerapan Social Distancing atau Physical Distancing dan penerapan new normal serta gerakan menggunakan masker dalam bentuk poster yang disampaikan dengan cara memanfaatkan media sosial instagram sebagai sarana edukasi dalam upaya meminimalisir dampak covid-19 serta membagikan masker, hand sanitizer serta sterilisasi fasilitas umum dan fasilitas sosial kepada masyarakat yang dilaksanakan oleh Mahasiswa Peserta KKN Tematik Universitas Halu Oleo di lokasi masing-masing peserta KKN Tematik dengan tetap menerapkan protokol kesehatan. 
Kegiatan pengabdian terintegrasi KKN Tematik ini dilaksanakan mulai tanggal 12 Juni 2020 sampai 12 Juli 2020. Lokasi KKN Tematik berdasarkan lokasi peserta KKN Tematik yakni di Kota Kendari, Kabupaten Bombana, Kabupaten Muna, Kabupaten Buton, Kabupaten Buton Selatan, Kabupaten Buton Tengah, Kabupaten Kolaka, Kabupaten Kolaka Timur, Kabupaten Kolaka Utara, Kabupaten Konawe Selatan dan Kabupaten Konawe Utara.

\section{B. HASIL DAN PEMBAHASAN}

Kegiatan pengabdian terintegrasi KKN Tematik ini dilaksanakan dengan memanfaatkan media poster dan partisipasi secara langsung kepada masyarakat sebagai bentuk edukasi kepada masyarakat yang dilakukan oleh mahasiswa sebagai peserta KKN Tematik. Adapun kegiatan yang dilakukan adalah sebagai berikut:

\section{Langkah Pencegahan Penyebaran Covid-19}

Langkah Pencegahan Penyebaran Covid-19 yaitu dengan membiasakan diri mencuci tangan, Hindari menyentuh area wajah, Hindari berjabat tangan dan berpelukan, bersihkan perabotan di rumah, Jaga jarak, dan Hindari berkumpul dalam jumlah banyak. Langkah pencegahan covid-19 dilakukan dengan cara berkunjung secara langsung ke rumah warga dengan menggunakan media poster dan dilaksanakan dibeberapa daerah antara lain di Kelurahan Korumba Kecamatan Mandonga Kota Kendari, Kelurahan Ranomeeto Kecamatan Ranomeeto Kabupaten Konawe Selatan, Desa Nggulanggula Kabupaten Buton Selatan, Kelurahan Mangolo Kecamatan Latambaga Kabupaten Kolaka, dan di Kelurahan Teomokole Kecamatan Kabaena Kabupaten Bombana.

\section{Sosialisasi Mengenai Social Distancing atau Physical Distancing}

Social distancing merupakan salah satu langkah pencegahan dan pengendalian infeksi virus corona dengan menganjurkan orang sehat untuk membatasi kunjungan ke tempat ramai dan kontak langsung dengan orang lain. Sosialisasi dilakukan dengan memanfaatkan media poster yang dilakukan dibeberapa daerah antara lain di Kelurahan Laiworu Kecamatan Batalaiworu Kabupaten Muna, Kelurahan Tobuuha 
Kecamatan Puuwatu Kota Kendari, Kecamatan Wawonii Utara Kabupaten Konawe Kepulauan, Kelurahan Takimpo Kecamatan Pasarwajo Kabupaten Buton, dan Kelurahan Lara Kecamatan Tirawuta Kabupaten Kolaka Timur.

\section{Penerapan New Normal}

Pemerintah telah menghimbau agar masyarakat bersiap untuk new normal atau menerapkan kebiasaan baru dalam menjalankan aktivitas sehari-hari. Sosialisasi dilakukan dibeberapa daerah antara lain di Kelurahan Lahundape Kecamatan Kendari Barat Kota Kendari, Kelurahan Lakudo Kecamatan Lakudo Kabupaten Buton Tengah, dan Kelurahan Balandete Kecamatan Kolaka Kabupaten Kolaka.

\section{Pengetahuan Tentang Covid-19}

Coronavirus Disease 2019 (Covid-19) adalah penyakit yang belum pernah diidentifikasi sebelumnya pada manusia. Virus penyebab Covid-19 ini dinamakan SarsCov. sehingga diperlukan suatu wujud nyata untuk mengedukasi agar terhindar dari penyebaran covid-19. maka dilakukan sosialisasi di Kelurahan Lahundape Kecamatan Kendari Barat Kota Kendari, Kelurahan Kambu Kecamatan Kambu, Kelurahan Balandete Kecamatan Lepo-Lepo, dan Kelurahan Tobuuha Kecamatan Puuwatu.

\section{Gerakan Menggunakan Masker}

Gerakan menggunakan masker merupakan pelengkap dari gerakan DirumahAja dan jaga jarak untuk menekan potensi penularan penyakit covid-19. Dilakukan dengan cara membagikan masker kepada masyarakat agar dalam melaksanakan aktivitas diluar rumah selalu menggunakan masker. Sosialisasi dilakukan dibeberapa daerah yaitu di Kelurahan Mokoau Kecamatan Kambu Kota Kendari, Kelurahan Lawatue Kecamatan Poleang Utara Kabupaten Bombana, Kelurahan Balandete Kecamatan Kolaka Kabupaten Kolaka, dan Kecamatan Wiwirano Kabupaten Konawe Utara.

\section{Sterilisasi Fasilitas Umum dan Fasilitas Sosial}

Sterilisasi fasilitas umum dan fasilitas sosial merupakan salah satu wujud nyata dalam mencegah penyebaran covid-19. Kegiatan tersebut terlaksana dengan cara berkerja sama dengan Palang Merah Indonesia (PMI) Kota Kendari untuk melakukan 
penyemprotan dirumah warga dan fasilitas umum agar mengurangi potensi penularan penyakit COVID-19 yang di laksanakan di Kelurahan Korumba Kecamatan Mandonga Kota Kendari.

Semua kegiatan yang dilaksanakan seperti yang dijelaskan diatas dimuat dalam media sosial instagram dengan menggukan akun "kkntematik.fhuho" dengan harapan bahwa masyarakat yang tidak terakomodir dalam pelaksanaan kegiatan pengabdian dapat memanfaat media sosial instagram tersebut sebagai bahan edukasi kepada masyarakat.

Hasil evaluasi pelaksanaan kegiatan pengabdian penanggulangan covid-19 ini dilakukan mulai dari tahap sosialisasi dengan menggunakan media poster sampai dengan berpartisipasi secara langsung seperti membagikan masker dan melakukan penyemprotan atau sterilisasi fasiltas umum dan sosial bekerjasama dengan PMI Kota Kendari . Hasil evaluasi tersaji dalam tabel 1 berikut ini.

Tabel 1. Hasil Evaluasi Pelaksanaan Kegiatan Pengabdian

\begin{tabular}{|c|l|c|}
\hline No. & \multicolumn{1}{|c|}{ Aspek } & Presentase \\
\hline 1 & $\begin{array}{l}\text { Pemahaman dan pengetahuan atas } \\
\text { kegiatan yang dilaksanakan dengan } \\
\text { menggunakan media sosial }\end{array}$ & $80 \%$ \\
\hline 2 & $\begin{array}{l}\text { Partisipasi masyarakat selama kegiatan } \\
\text { pengabdian berlangsung }\end{array}$ & $90 \%$ \\
\hline 3 & $\begin{array}{l}\text { Respon masyarakat terhadap kegiatan } \\
\text { pengabdian }\end{array}$ & $85 \%$ \\
\hline 4 & $\begin{array}{l}\text { Kegiatan pengabdian tersebut menarik } \\
\text { minat masyarakat }\end{array}$ & $85 \%$ \\
\hline
\end{tabular}

Hasil evaluasi kegiatan pengabdian ini masyarakat mampu memahami dan mengetahui seluruh kegiatan penbadian yang dilaksanakan dalam upaya meminimalisir dampak covid-19 di Sulawesi Tenggara yang ditunjukan dengan hasil yang baik. Hal ini dapat dilihat dari antusias masyarakat dengan memberikan respon positif atas kegiatan yang dilakukan terkait dengan pencegahan covid-19 serta dapat menarik minat masyarakat dan mengharapkan kegiatan seperti ini agar terus berlangsung secara berkesinambungan. 


\section{KESIMPULAN}

Berdasarkan hasil kegiatan pengabdian terintegrasi KKN Tematik penannggulangan covid-19 dapat disimpulkan bahwa peserta KKN Tematik telah melaksanakan program kerja yaitu: 1) sosialisasi atau penyuluhan kepada masyarakat mengenai pencegahan Covid-19 seperti penerapan social distancing atau physical distancing dan penerapan new normal serta cara menggunakan masker dalam bentuk poster dan 2) membagikan masker, hand sanitizer serta sterilisasi fasilitas umum dan fasilitas sosial kepada masyarakat bekerjasama dengan Palang Merah Indonesia di Kota Kendari. Semua program tersebut disampaikan dengan cara memanfaatkan media sosial instagram sebagai sarana edukasi dalam upaya meminimalisir dampak covid-19. Hasilnya menujukan bahwa tingkat pemahaman dan pengetahuan masyarakat dalam upaya mencegah dan meminimalisir dampak covid-19 di Sulawesi Tenggara baik dan kegiatan pengabdian tentang penanggulangan covid-19 sangat membantu dan memberikan kemudahan bagi masyarakat Sulawesi Tenggara dalam mencegah penyebaran covid-19. Namun diperlukan bantuan dari pemerintah dalam penanggulangan covid-19 dengan seperti pembagian masker dan antiseptik/hand santizer serta peran serta masyarakat dalam mencegah dampak covid-19 di wilayah masing-masing.

\section{UCAPAN TERIMAKASIH}

Ucapan terima kasih kepada Lembaga Penelitian dan Pengabdian Pada Masyarakat Universitas Halu Oleo, Pemerintah Kota Kendari, Kabupaten Bombana, Kabupaten Muna, Kabupaten Buton, Kabupaten Buton Selatan, Kabupaten Buton Tengah, Kabupaten Kolaka, Kabupaten Kolaka Timur, Kabupaten Kolaka Utara, Kabupaten Konawe Selatan dan Kabupaten Konawe Utara yang menjadi lokasi peserta KKN Tematik, peserta mahasiswa KKN Tematik dan semua pihak yang telah membantu pelaksanaan kegiatan ini. Semoga kegiatan ini dapat bermanfaat bagi semua pihak dalam rangka peningkatan mutu kehidupan sosial masyarakat dan pengambangan tridharma perguruna tinggi yang sesuai dengan visi dan misi Universitas Halu Oleo. 


\section{DAFTAR PUSTKA}

Kementerian Kesehatan RI, Direktorat Jenderal Pencegahan dan Pengendalian Penyakit (P2P) 2020. Pedoman Kesiapsiagaan Menghadapi Coronavirus Disesase (Covid19).

Badan Pusat Statistik Sulawesi Tenggara. Sulawesi Tenggara Dalam Angka Tahun 2019.

Kementerian Dalam Negeri RI. Pedoman Umum Menghadapi Pandemi Covid-19 Bagi Pemerintah Daerah, Pencegahan, Pengendalian, Diagnosa dan Manajemen.2020.

https://www.kompasiana.com/restynurdiantikaramadhanti/5e73327ed541df1e9b0f67d4 /media-sosial-sebagai-media-komunikasi-pemerintah-dalam-menanggulangicovid-19, diakses tanggal 23 April 2020 